\title{
The Metabolism of Socioecological Fixes: Capital Switching, Spatial Fixes, and the Production of Nature
}

\author{
Michael Ekers and Scott Prudham
}

\section{QUERY SHEET}

This page lists questions we have about your paper. The numbers displayed at left can be found in the text of the paper for reference. In addition, please review your paper as a whole for correctness.

Q1. Au: Please provide a cite in text and a complete corresponding entry in your references for this work by Ondaat $\Omega$

Q2. Au: Swyngedouw and Kaika 2000 is not given in your references. Please either add a full entry there or delete the citation here.

Q3. Au: Please provide a page number for this quotation from Swyngedouw and Kaika 200

Q4. Au: Please include any Funding details to be formally acknowledged in this articl 2

Q5. Au: Kaika and Swyngedouw 2000 is not cited in text. Please either add a citation there or delete the entry her

Q6. Au: Sullivan 2013 is not given in your references. Please either add a full entry tha or delete the citation her $\Omega$

Q7. Au: Walker 1981: Please provide name and location of publisher for this entry

Q8. Au: Please provide full mailing address for Eker

Q9. Au: Please provide full mailing address for Prudhan

\section{TABLE OF CONTENTS LISTING}

The table of contents for the journal will list your paper exactly as it appears below:

The Metabolism of Socioecological Fixes: Capital Switching, Spatial Fixes, and the Production of Nature Michael Ekers and Scott Prudham 


\section{The Metabolism of Socioecological Fixes: Capital Switching, Spatial Fixes, and the Production of Nature} plant, the largest of its kind in Toronto. The other is the iconic R. C. Harris water treatment plant, a drinking water intake, processing, and distribution facility featured memorably in Ondaatje's In the Skin of a Lion.

0 Although not without their distinguishing features (indeed, the Harris plant is an architectural landmark), such facilities are nevertheless-typical of metropolitan infrastructure in contemporary cities. They are also excellent examples of the sorts of intensive fixed 35 capital projects theorized by David Harvey (and others after him) as spatial fixes. That is, they are elements of the built environment produced by means of diverting or "switching" capital flows into enduring, spatially explicit infrastructures that facilitate commodity prosupporting social reproduction more broadly.

We begin with these two examples of spatial fixes because, even as they feature prominently in the city's spatial infrastructure, they are also implicated rather

self-evidently in transformations of nature, or better, socionatures. Each anchors an extensive network of largely hidden pipes and pumping stations, one circulating sewage and the other drinking water. They underpin the almost magically mundane provision of vital urban socionatural inputs and services, exemplifying what Swyngedouw and Kaika (2000) memorably characterized as the "phantasmagoria of urban technological networks," As central nodes in such networks, both the Ashbridges Bay facility and the R. C. Harris plant are thus important pieces of Toronto's "urban metabolism": networked flows of energy and raw materials tied to associated labor processes, institutions, and ideological framings of "nature" and the "city" that sustain and constitute processes of urbanization (Gandy 1999, 2002; Keil 2003; Kaika 2005; Heynen, Kaika, and Swyngedouw 2006).

The question that immediately comes to mind, of course, is whether such facilities are exceptional in fusing the production of space and the production of nature through fixed capital formation. Or, alternatively, do they point to a broader general dialectical unity? We argue the latter. It is relatively intuitive to see connections among the production of space, the production of nature, fixed capital formation, and the built environment of the city when considering facilities such as these. Yet, in this article, we contend that the formation of spatial fixes through capital switching and fixed capital formation, as theorized primarily by 
Harvey, needs to be understood as an inherently meta-

75 bolic process; that is, as an important site where the production of space and the production of nature happen together as differentiated but coconstituted unities. One of our central purposes in this article, and in the companion piece to follow, is to make this argu80 ment systematically.

Although we advance the notion that fixed capital formation arising from spatial fixes is always a metabolic process, we also contend that exploring, understanding, and contesting the production of nature, environmental 85 politics, and environmental regulation in the guise of spatial fixes is a crucially important intellectual and political agenda in the current conjuncture. A myriad of serious contemporary socioecological challenges is drawing more attention to the socioecological foot-

90 prints of infrastructure and also animating calls to invest in greener technologies, perhaps most pressingly in greenhouse-gas-intensive domains such as energy production, transportation, and buildings (see, e.g., Urry 2004; Sayre 2010; Huber 2013; Castree and Chris95 tophers 2015; McCarthy 2015). ${ }^{1}$ Yet we argue that arguments pertaining to specific, ostensibly more environmentally relevant infrastructure in turn points to the need to confront the role of landscapes in general and fixed capital in particular-whether rural or 100 urban-in constituting socioecological conditions, and equally, to consider the political ecological conditions for producing and ultimately transforming them. This includes the need to critically engage with systemic tendencies by capitalist firms to target socionatures as 105 an "accumulation strategy" (Katz 1998; see also Smith 2007) and to appraise associated outcomes that could range from potentially progressive technological and organizational innovations to corporate greenwash and the cooptation of ostensibly green agendas (e.g., organic 110 foods; see Guthman 2004).

In this article and a companion piece to follow, we develop the concept of the socioecological fix to capture the ways in which the social relations and material and symbolic conditions of capitalist accumulation are

115 reproduced through investments in landscapes that are simultaneously and always conjoined productions of space and nature. Our core argument involves developing a perspective that sees capital switching and fixed capital formation as metabolic processes. We 120 agree with Harvey and others that durable forms of capital must be seen as comprising material conditions underpinning the reproduction of capitalist accumulation, but also as infrastructures integral to the architecture of social reproduction more generally, including via the production of the socionatures of everyday life. 125 This entails, in turn, recognizing that capital sunk into the landscape is also subject to social struggles that shape matter and meaning, including in socioecological registers, and that these struggles in turn comprise part of the ideological terrain of legitimacy and hegemony in a complex society (these latter themes are particular points of emphasis in the second article).

This article unfolds as follows. In the next section, we provide a brief survey of some literature relevant to our project and comment on the question of nomenclature. Subsequently, we review the significant features of Harvey's theory of the spatial fix. The theory, developed through numerous publications, represents a uniquely valuable contribution to the development of a specifically geographical take on the dynamics of capital accumulation. We note two lacunae important to our argument in this article and the second, however. The first is an underemphasis on capital switching and fixed capital formation as important avenues in the production of nature. The second is the relative underdevelopment in Harvey's work of the ways in which spatial fixes emerge as the products of social struggle and contestation, arising from contingent and thoroughly political processes, which are (formally) economic and (formally) noneconomic (i.e., political, cultural, socioecological, etc.) in substance. After reviewing and commenting on the essential features of the theory of the spatial fix, we turn to Neil Smith's production of nature thesis to develop a specific foundation for working through the socioecological "moment" of spatial fixes. We note, though, that Smith leaves relatively unexamined contradictions and crises internal to the production of nature; more specifically, we argue that Smith's account, much like Harvey's, downplays the role of political struggle and contestation in actively constituting the specific trajectory of socioenvironmental change. The final section builds on these insights to emphasize the ways in which inherent tensions between capitalist production and wider questions of social reproduction are manifest in the production and (we suggest cautiously, drawing from the work of James O'Connor) the underproduction of socionatures.

\section{Some Antecedents}

Of course, we cannot claim to be the first to explore the socioecological character of various fixes. The core themes discussed in this and the companion piece have been approached by others either implicitly 
within general discussions of capitalism, space, and

175 nature or through more explicit discussions of environmental or sustainability fixes. In this brief section, we highlight some of those contributions.

In the most general terms, Moore (2011) argued that "[c]apitalism does not have an ecological regime: it is an

180 ecological regime" (2, italics in original). His recent book Capitalism in the Web of Life (Moore 2015) considers the survival of capitalism through both plunder and capitalization, but explicit concern with the role of fixed capital and hegemony in socionatural fixes is

185 largely unexplored. For his part, Harvey (1996) memorably noted, "all ecological projects (and arguments) are simultaneously political-economic projects (and arguments) and vice-versa" (182). Despite this and related statements, the socioecological dimensions of

190 spatial fixes and fixed capital remain largely implicit in his work. More directly, Smith ([1984] 2008) proposed a theory of the conjoined production of nature and space as a way of accounting for the reproduction of capitalism, a theory from which we draw heavily.

195 Smith, though, did not systematically focus on capital switching, fixed capital, or the dynamics of spatial fixes in his development of a theory of the production of nature. In contrast, Mitchell (1996, 2000, 2003; see also Herod 1997) developed the concept of landscape

200 specifically as a way to understand how productive forces are built into land as fixed capital, with emphasis on both the material character and ideological significance of produced landscapes in constituting the socioenvironmental conditions of everyday lives including

205 specific, concrete labor processes. Also highly relevant in a more specific, substantive sense is scholarship linking (sub)urban form, fossil fuels, the internal combustion engine, and so on, into an account of a wider "automobility" (Urry 2004; see also Huber 2013).

210 To be sure, various writers have begun to introduce rhetoric linking socioecological, ecological, sustainable, and other kinds of institutional, technological, or regulatory fixes to environmental problems and concerns. Castree (2008), for instance, in reviewing the

215 extensive literature on "neoliberalism and nature," discussed what he called various "biophysical fixes" achieved or attempted by neoliberal reforms. His emphasis, however, was more on the systemic offloading of responsibility for socioenvironmental changes

220 that underpins much neoliberal environmental regulatory reform, offloading that he suggested opens up areas for accumulation but also potentially crises of legitimacy. Others have similarly explored the notion of a "regulatory fix" in environmental governance (see, e.g., Bakker 2003; While, Jonas, and Gibbs 2004; 225 Macdonald and Keil 2012; Cohen and Bakker 2014). Guthman $(2011,2015)$ suggested that human bodies comprise opportunities for socioecological fixes to the contradictions of the capitalist food system even though her emphasis was not on fixed capital formation per se. It bears noting that her 2015 article on the subject is part of a themed collection on which we collaborated and the remit of which was to explore the concept of socioecological fixes. ${ }^{2}$ The collection also notably includes Nugent's (2015) article examining the development of a political coalition pressing for (ostensibly) green infrastructure renewal (much of it in Toronto) as a spatial and socioecological fix in the province of Ontario (Nugent 2015). Others, too, have begun to explore and make explicit socioecological dimensions of Harvey's theory of the spatial fix with a focus on the role of capital switching (e.g., see Kear 2007; Castree and Christophers 2015). Swyngedouw's (2015) account of the modernization of Spain during the twentieth century as a project actively constituted by the harnessing and transformation of the nation's hydrologic resources also comes as close as anything we could name in providing a substantive, historical, geographical exploration of the notion of socioecological fixes along the lines we seek to develop.

These examples aside, however, to our knowledge, there has not been a systematic attempt to explicitly examine and develop Harvey's notion of the spatial fix, with attention to the relations among dynamics of capital switching; fixed capital formation; the production of space and nature; and the political, economic, and cultural logics of crisis and legitimacy. As a consequence, the uptake of Harvey's theory of the spatial fix as such remains largely focused on the exclusively spatial dynamics of (mostly) urban restructuring in response to crises of overaccumulation and devaluation while leaving socioenvironmental change and environmental politics out (see, e.g., Brenner 1998; Wyly, Atia, and Hammel 2004; Glassman 2007; Smith [1984] 2008; Lang and Knox 2009). Conversely, much of the literature explicitly discussing environmental fixes under various guises has curiously steered clear of a sustained engagement with Harvey and has largely bypassed his earlier work on fixed capital and the built environment (for exceptions see Kear 2007; Castree and Christophers 2015). This article and the one to follow are intended to help close the loop when it comes to the metabolism of capital switching and fixed capital formation in the context of spatial fixes induced by crises of capitalist accumulation. 


\section{Nomenclature}

One of our priorities in these articles is to challenge and contribute to subsuming problematic dualisms. We examine how spatial fixes not only transform the 280 built environment via fixed capital formation, but also simultaneously and necessarily remake the environments and landscapes of commodity circulation and everyday life more generally. Pursuing this theme requires negotiating a number of dualisms that pervade

285 popular renderings of the world and that also reference matters central to geographical inquiry, namely, nature-space, nature-society, production-reproduction, and materiality-ideology. Without doubt we unwittingly reproduce some of these and other dualis-

290 tic conceptions over the course of these two articles. Before proceeding, though, we offer some preliminary comments on the nomenclature to which we attempt to adhere.

Centrally, we deploy the term and the concept of

295 metabolism to express the mutual transformation of society, nature, and space through the social deployment of human labor, broadly understood, to the transformation of the world around us. Drawing on nineteenth-century organic and soil chemistry, Marx

300 ([1867] 1977) adopted the terminology of stoffwechsel (material exchange) to apply a rubric of mutual transformation to the relationship between human labor and nature (writ large). For Marx, this metabolic foundation provides a single point of departure for

305 historical materialism, grounding the analysis and explanation of distinct forms of social organization in the manner in which societies of different kinds organize the deployment of labor to produce their material wants and needs and to secure their social reproduc-

310 tion (Foster 1999). Increasingly, the terminology and ethos of metabolism is being taken up in critical environmental studies, geography, and political ecology (including, e.g., in urban political ecology; see, e.g., Swyngedouw and Heynen 2003) as a way of transcend-

315 ing nature-society and space-society dualisms, but also as a way of affording an active, constitutive role to lively nonhuman entities and processes in accounts of social change and differentiation. In this vein, our emphasis on the metabolism of landscape transforma-

320 tion aims to capture the conjoined social and ecological character of historical-geographical processes of fixed capital formation.

In grounding our argument in the concept of metabolism, we use the term nature sparingly and typically, 325 following Smith, informed by the notion that what we encounter as nature has a historicity to it, and more specifically, that it is an artefact of the direct or indirect transformation of biophysical processes and entities by social labor. Following others working in various fields, we use the admittedly clumsy adjectives socionatural and socioecological whenever possible to try to express the simultaneity of sociospatial and environmental change. Although we are certainly aware of the productive and provocative use of terminology such as hybridity and cyborg to achieve similar purposes, 335 we chose less rhetorically fluid terms as ways of forcing ourselves and our readers to revisit and actively trouble dualisms that are all too real in the everyday world of ideas and language and that do real work on the objects to which they refer (and on the subjects who use them as referents). We are committed to transcending nature-society and space-nature dualisms in these works, but we are also attentive to the fact that all the remonstrances and niceties delivered in the comfort of philosophical abstraction cannot subvert the fact that dualistic thinking, speaking, and doing remain potent norms. Accounting for the work these norms do, even in trying to change them, is also part of the struggle.

In advancing our arguments, we also recognize the complex relationship between representational and material processes and practices. Followg the likes of Gramsci (1971) and others drawing on his work (Hall, Lumley, and McLennan 1977; Thomas 2009; Rehman 2014), we understand the concept of ideol egy not as merely the domain of abstract and sometimes illusory if not fanciful ideas, but as material forces in and of themselves constituted in material practices. This perspective makes plain why we cannot simply wish away categories like nature, the city, or 360 the country. Such notions continue to have powerful effects in structuring social action. At the same time, and as we take up centrally in the companion piece, ideologies are very much immanent to, and expressed through fixed capital. The amassing of fixed capital in infrastructure and landscapes, although classically considered as "concrete and clay," to borrow from Gandy (2002), is always much more dynamic and ideologically charged than any strict confinement to physical forms might suggest.

\section{Harvey and the Spatial Fix}

Developed in numerous publications over the span of many years, Harvey's theory of the spatial fix is one 
of his signature contributions to a spatially explicit 375 theory of capital accumulation. Encapsulated in Harvey's (2001) words, the spatial fix refers simply to "capitalism's insatiable drive to resolve its inner crisis tendencies by geographical expansion and geographical restructuring" (24).

380 Harvey (1981) attributed the genesis of the question "Is there a 'spatial fix' to capital's problem?" (415) to Hegel's ([1821] 1991) Elements of the Philosophy of Right. For Hegel, bourgeois society featured an inherent tendency to generate both increasing wealth and

385 poverty. In addition to worsening social inequality, the result Hegel identified was a shortfall of demand within the boundaries of a territorially prescribed (e.g., national) market and thus an unrealized surplus production (Harvey 1982, 414). Hegel argued that this

390 tendency would give rise to an expansionary impulse motivating (in part) colonial conquest and imperial war in the absence of other mechanisms of resolving it.

Harvey, however, turned to Marx for a more detailed specification of the tendency, which, Marx

395 argued, originates in capitalism's DNA. Thess the problem is capitalist ofuction of commodities as and ond in agregate magnitude of social demand for commodities and based on an inherently exploitive capitalist wage relation.

400 Under these conditions, with production aimed at gain (i.e., maximizing surplus) rather than need, the consequences (all else being equal) are a disarticulation of supply and demand in general coupled with a specific tendency toward overaccumulation or excess value

405 production. Overaccumulation might be manifest as some combination of surplus capital looking for productive investment, surplus commodities looking for buyers, and surplus labor power looking for productive employment. ${ }^{3}$ Ignoring a number of attenuating influ-

410 ences, the potential consequences include devaluation of existing capital investments and commodities in circulation, downward pressure on wages or employment, and capital flight.

This, in very simplified terms, is a sketch of

415 Harvey's notion (derived from Marx) of the systemic tendency toward crises of overaccumulation. These tendencies might or might not become manifest as a generalized economic crisis affecting most of the capitalist economy, depending on historical circumstances,

420 including regulatory mechanisms, other forms of social intervention, and the character and scope of the geographical integration of commodity markets. As Harvey (1975) noted, overaccumulation can also be an international phenomenon, it can be a national or regional phenomenon, and it might be manifest unevenly across economic sectors. The specifics are matters of historical-geographical detail and contingency.

The spatial fix is Harvey's term for the ways in which response to these crisis tendencies occurs by means of some form of reset or fix with specific geographical characteristics. Harvey (2001) explained that his choice of the word fix deliberately draws on the word's multiple connotations, including:

1. To fix in place.

2. The fixing of a problem by returning things to some functioning state, again with emphasis for Harvey on this taking spatial form.

3. A response to addiction (i.e., the "user's" fix) resolving an underlying craving or need whose specifically spatial resolution can only be temporary.

4. A technological fix, with emphasis on the spatial character of relatively large-scale technologies or technological systems.

5. A spatial outlet for capitalist crisis tendencies through geographical expansion, resulting in the temporary "fixing" of the problem by means of opening up new spaces of commodity circulation and capital accumulation.

6. A reference, inspired by a close reading of Marx's Capital (Vol. II) and the Grundrisse, to the significance of enduring forms of capital investment that become embedded or fixed in the landscape and thereby immobilized or locked into place. (24)

For Harvey, crisis acts as an "irrational rationalizer," resulting in distinct geographies of commodity circulation, capital accumulation, and social reproduction whose spatial arrangements "work," at least temporarily, but in ways that result in an inherent tension between fixity and mobility. Specifically, the locking in of spatial arrangements facilitates movement but at the expense of sacrificing the mobility of that portion of the social capital locked into place. In addition, the process of rationalization, for Harvey, is expressed in some combination of two moments, one "outer" and the other "inner." These moments correspond, respectively, to extensive or expansionary tendencies and intensive or reorganizational and restructuring ones. Glassman (2007), in a highly useful summary of Harvey's specific theory of crisis and of the formation of spatial fixes, deployed the language of

425 
"decentralization" and "centralization," respectively, 475 to capture these twin moments.

The gist of the "outer" or decentralizing moment is perhaps more intuitive and familiar. Indeed, it is one of the central aspects of Hegel's formulation discussed earlier. The idea in simple terms is that the mismatch

480 between supply and demand within any given territorially bounded and defined market might create pressure to expand spatially to open new pathways for investment flows and to open new markets for commodity sales. Alternatively, falling rates of profitability

485 as the result of increasing wages or rising prices for raw material inputs or escalating expenditures on fixed capital might propel an outward search for cheaper sources in new locations. Notably, expansionary or decentralizing tendencies might take place within

490 nation-states, resulting in decentralizing interregional reorganization or restructuring. Alternatively, decentralization might manifest itself internationally, opening up the possibility of capital flight from one nation-state to another or the integration of some

495 combination of national capital, commodity, and labor markets (Glassman 2007).

The inner or centralizing moment refers to spatial fixes that have a more in situ character, featuring some combination of efforts to deepen market capacity for

500 absorbing investments and commodities within an existing regionally defined market, whether that be within nation-states, regions, or cities. A key dynamic involves the investment of fixed capital into the built environment in ways that have the effects of (1)

505 absorbing surplus capital and thus relieving the pressure of overaccumulation; and (2) restructuring and improving the spatial infrastructure of commodity circulation and social reproduction. The inner moment of a fix thus entails both quantitative changes (absorp-

510 tion of surpluses and the acceleration of production and circulation) and qualitative transformations (development of new conditions, processes, and experiences of production and reproduction).

This second or centralizing moment of the spatial

515 fix is arguably the more original of Harvey's insights. It has comprised the focus for significant development of the theory with emphasis on the relationship between capital investments and the production of specifically urban landscapes. It is clear, however, that although

520 the two moments of spatial fix are usually discussed distinctly in Harvey's work, they are best understood as having a conjoined and relational character. Decentralization in one place might lead to centralization in another, whereas centralizing tendencies within a particular city or region (e.g., development of fixed 525 capital underpinning long-distance trading networks and the logistics industry-see, e.g., Cowen 2014) might be tied to dynamics of decentralization when viewed from the perspective of another. As Harvey (1982) put it, "the distinction between 'inner' and 'outer transformations' becomes hard to isolate" (426).

Our focus, within this dialectic of centralization and decentralization, is on Harvey's conception of capital switching leading to the formation of longer term investments in the built environment as an aspect of the spatial fix framework. Drawing on Marx's contrast between circulating and fixed capital (extensively discussed in Volume II of Capital), Harvey stressed the significance of forms of capital that become "sunk" into longer lasting forms. He noted that these take on two basic guises. The first is fixed capital (i.e., relatively enduring forms of invested capital the value of which is given up or realized relatively slowly over the course of several production cycles ${ }^{4}$ ), the form of which is relatively fixed in immobile, spatially explicit infrastructure (thereby, as Harvey put it, "doubly fixed" in time and in space). One might think for instance, and apropos our emphasis on the socionatural character of fixed capital, of the difference between grapes (conventional commodities produced on an annual basis) and grape vines (fixed capital, producing grapes on an annual basis but with life cycles perhaps decades long). The second form of sunk capital of interest here goes into the spatial infrastructure of the consumption fund in the form of fixed assets that facilitate consumption but the value of which, in parallel with fixed capital, is also not fully realized in single cycles of use (e.g., social infrastructure such as hospitals and public roads). Importantly, some forms of relatively fixed assets function as both fixed capital and consumption fund (e.g., 560 roads and shopping malls; Harvey 1989b).

At the most abstract level, relatively enduring assets existing as fixed capital and the consumption fund that become immobilized in space are essential elements of the space economy because commodities must circulate from place to place; workers must move from home to work; and production, reproduction, and consumption must take place in and among specific places. Moreover, these fixed assets have spatially distinct and explicit features. Thus, sunk capital diverted into the landscape as relatively enduring forms of economic and social infrastructure is implicated in the production of space writ large, and thus in the dynamics of uneven development and the experience of sociospatial differentiation (Harvey 1976, 1982). 
Crucial to Harvey's theory of how surplus capital flows into relatively enduring forms of the built environment is his model of circuits of capital investment and periodic "switching crises." Working again from 580 Marx's various (and variously completed) texts, Harvey $(1978,1982,1985 a, 1985 b)$ has argued that there are three circuits of capital investment flows: the primary, the secondary, and the tertiary. The primary circuit is defined by production and consumption of

585 commodities within a single time period (say, one year, although this is not necessarily the case). Because there is a tendency to produce more exchange value than can be realized in the market within a single production cycle (assuming a territorially bound and

590 closed market $\_a s$ Harvey's model doest, overaccumulation and the resulting threat to value can be ameliorated by diversion of some portion of capital into secondary and tertiary circuits that have longer turnover times. The secondary circuit involves flows into

595 the formation of fixed capital and the consumption fund (see earlier). Finally, the tertiary circuit involves flows of capital into the reproduction of capitalism and social reproduction more broadly, including scientific and technological research and development, educa-

600 tion, health care, and so on. As should be clear, our focus is on the secondary circuit as conceived by Harvey, albeit embedded within the larger conceptual apparatus. We are concerned with how sunk capital leads not only to the production of space, but also to

605 the production of landscapes in a more holistic sense, and this to the production of nature as prevailing socioenvironmental conditions.

Several observations are warranted by way of closing our review of Harvey's multifaceted conception of

610 the spatial fix. First, the spatially explicit character of longer term investments in the built environment carries a specific dual connotation of fix, as Harvey stressed. The fix means, on the one hand, literally to fix the overaccumulation problem fianding an outlet

615 for surplus capital or an influx of cheaper labor and raw materials while improving the efficiency of commodity circulation and social reproduction within spatially explicit infrastructural arrangements. The fix also means, though, fixity as geographical arrange-

620 ments take on relatively enduring and sometimes highly inert forms. These arrangements become fixed in place and their embodied capital is likewise "locked in." As such, although sinking capital into the built environment might present a solution to overaccumu-

625 lation in one sense, it also establishes the conditions or rigidities (to use Harvey's phrasing) against which subsequent crises develop. What is at one time a solution becomes later a new problem. For Harvey, this is the central dilemma or contradiction of sunk capital as a form of spatial fix. In his words, "[v]alue has to be immobilized in the land to an increasing degree ... in order to achieve spatial integration and to eliminate spatial barriers to the circulation of capital. At some point or other, the value embodied ... becomes the barrier to be overcome" (Harvey 1982, 380).

Second, the longer term character of many of the investments achieved via capital switching means that crises are offset not only through the production of space, but through temporal displacement. This underpins Harvey's conception of "spatio-temporal fixes" (Jessop 2006). Immediate threats of devaluation might be addressed through the embedding of fixed capital into enduring forms of spatial infrastructure, but these tendencies in turn also posit extended temporal horizons for the realization of value. Forestalling the realization of invested value in turn increases the risk that the investments in question will be subject to devaluation due to unforeseen future circumstances (see Castree 2009), including, notably, via changing socioenvironmental conditions (e.g., climate change).

This immediately points, third, to the singular importance of finance capital in facilitating the flow of capital into longer term investments (on this point specifically, see Harvey, 1982, Chapter 10, as well as Harvey 1989a). Whereas larger firms (e.g., multinational corporations) and investors drawing on concentrated asset pools (e.g., pension fund investors) might well be able to take on long-term, large-scale investments on their own, in many instances, the organization of numerous smaller enterprises into a coherent long-term trajectory of fixed capital investment requires the involvement of the banking and credit sectors-consider, for instance, the importance of relatively cheap consumer credit in underwriting mass home ownership as one facet of suburbanization in North America during the latter twentieth century (see, e.g., Walker 1981). The same might be said of the role of finance capital in creating the capacity to take on longer term and potentially risky debt for any set of private actors. One excellent example worked out in compelling empirical detail is Henderson's (1999) account of the role of finance capital in facilitating the industrialization and intensification of California agriculture beginning in the late nineteenth century.

Fourth, and conversely from the previous point, there is generally a weak incentive for individual 
capitalists to pay for long-term, large-scale infrastructure initiatives, partly due to the costs involved, partly

680 due to the extended duration of sunk capital investments, and partly due to an increase in the risk of devaluation that attends longer term investments. In addition, many of the kinds of investments in the built environment that Harvey discussed as spatial fixes

685 involve "social" infrastructure with diverse users (e.g., roads, public transportation, communications networks, airports, or the two examples with which we began this article). Individual private investors might not expect sufficient return to warrant investing in 690 these kinds of projects on their own.

A main result of the two aforementioned points, as Harvey (1989b) put it succinctly, is that "[i]ndividual capitalists tend to over-accumulate in the primary circuit and to underinvest in the secondary circuit" (65).

695 This is a point of immense significance to thinking about how actual spatial fixes are organized socially, and it has important implications for our general argument about the political and cultural dimensions of socioecological fixes, a theme we return to later in this

700 article and in the article to follow. For now, it is important to recognize that in many instances, some form of involvement by governments, multilateral institutions, and financial firms will be necessary for large infrastructure projects, particularly those with a

705 collective or public character. Alternatively, institutional investors (e.g., pension funds) and sovereignwealth funds might also look to these large-scale infrastructure initiatives as exclusive investment opportunities (see Torrance 2008; Loftus and March

710 2016), with important governance implications. In general terms, and as Harvey himself repeatedly noted, the actual "doing" of capital-intensive projects involving large-scale transformations of the built environment through the diversion of sunk capital, whether

715 in urban settings or otherwise, is likely to involve the formation of complex coalitions of social actors, and indeed, to lead to complex politics of struggle and contestation over the specific trajectory and ultimate legitimacy of such projects (one thinks, for instance,

720 of the politics of siting almost any new large-scale energy generating facility, be it a gas-fired electricity plant, a new hydroelectric dam or, increasingly, a wind farm). As we emphasize in the second article, securing consent for such projects is hardly incidental.

725 Yet emphasis on the politics of spatial fixes has largely taken a back seat to Harvey's analysis of their functional role in providing outlets for overaccumulated capital. This is categorically not to suggest that
Harvey is unaware of the important political and cultural dimensions of spatial fixes, capital switching, and fixed capital formation, particularly when it comes to aspects of the built environment with a collective or public character. He noted, for instance, that "[t]he state provides the single most important channel for flows of value into social infrastructure" (Harvey 1982, 404). He also pointed toward the importance of particular coalitions of social actors, including different factions of capital, in explaining the development of spatial fixes and investments in the built environment in real historical geographical conjunctures.

Developing an analytical framework that accounts for these political dimensions of the formation of spatial fixes, however, is something Harvey has generally not done. Largely, this is by design. In the introduction to Limits, for example, he wrote: "I wanted to get through the materials Marx assembled in the three volumes of Capital, the three parts of Theories of Surplus Value and in the Grundrisse in order to deal with the particular topics that interested me. There was no way to do it except by stripping the theory of any direct historical content" (Harvey 1982, xiv). Doing so, he acknowledged, was "a violation of the ideals of historical materialism" (Harvey 1982, xiv, italics added).

This "violation" is not without consequence. Jessop (2006), commenting on some of the strengths and weakness of Harvey's development of the theory of the spatial fix, wrote, "Harvey's analysis of temporal and spatial fixes is primarily value-theoretical. There is little explicit concern with the explanatory limitations of economic categories and, despite his emphasis on 'internal relations,' the extra-economic dimensions of the capital relation generally enter only in his more expansive and historically specific analyses" (161; for related observations, see Walker 2004). In this vein, Glassman (2007) commented:

A successful working-class struggle may lead to rising wages and a profit squeeze, a successful capitalist counterattack to declining wages and either underconsumption or the rising organic composition of capital. Moreover, overaccumulation itself is, in this view, a contingent outcome of class struggle. What constitutes an unacceptably large surplus of commodities, production capacity, or idle workers and what constitutes an unacceptably large decline in profit rates or an overly large fiscal deficit are not simply given technically, but are determined by 775 social actors struggling over outcomes. (351).

These observations point to the need to think carefully about the role of contestation, struggle, and

\section{0}

35

740

.

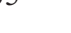

45


historical-geographical contingency as internal to the

780 formation of crises and to particular spatial fixes, shaping the trajectories of capital switching and the particular territorialization of economic processes and relations. Further, we argue that the same applies to the politics of socioecological fixes and the production

785 of nature through capital switching. We return to this theme after working to integrate the theory of the spatial fix with that of the production of nature.

\section{Spatial Fixes and the Production of Nature}

As we noted at the outset, until recently, the theory

790 of the spatial fix has not been linked systematically to material and ideological transformations of socionatures, and we do not have a rigorous exploration of the metabolism of spatial fixes in general terms. Although Harvey $(1993,1996)$ certainly indicated on several

795 occasions that there are political ecological dimensions to any political economic process or transformation, his claim remains general. To advance this agenda, we draw on the late Neil Smith's widely influential theory of the capitalist production of nature.

800 It must be said first that Smith, somewhat curiously, wrote little explicitly about the spatial fix per se. Nevertheless, Smith's writings are highly germane in as much as his main project in Uneven Development (Smith [1984] 2008) was to provide an integrated

805 account of the production of space and the production of nature, the latter of which he viewed as the prior process. Specifically, he argued that the historical development of capitalism meant that "space is no longer an 'accident of matter' but instead a direct

810 result of material production" (Smith [1984] 2008, 107), a process that has a metabolic fundamental character.

Smith's theory is derived fundamentally from the aforementioned Marxian conception of a "metabolism

815 of human beings with nature" (Smith [1984] 2008, 54, italics added) as the material foundation for social life and for historicizing distinct types of social formations. One of Marx's points of departure for historical materialism as a method of analysis was to consider the his-

820 torically specific ways in which social reproduction has been secured through the deployment of social labor in the transformation of biophysical nature (Sayer 1987; Marx [1858] 1981). As Loftus (2009) put it, Marx (and thus Smith) began "practically," with the

825 application of human labor in transforming the world around us. The concept of metabolism in this genealogy means that if the emergence of historically and geographically specific patterns of socionatural change are tied to particular social formations, the converse is also true: Social and environmental change, seen as a single metabolism, are truly conjoined and can only be "thought" together. Those who would (rightly) emphasize the need to attend to the "materiality" of social life and specifically to the constitutive role of "lively" differentiated materialities in explaining trajectories of historical geographical social change will not miss the significance of this point.

Moving from production in general to capitalist production, Smith argued that the defining feature of capitalism's particular metabolism is a shift from production for use to production for exchange. Put differently, the primary goal of capitalist production is the production of commodities or exchange values as ends unto themselves. This has far-reaching consequences in thinking about the capitalist production of nature for Smith. Drawing from Marx, Smith argued that the production of exchange values by wage labor results in the collective alienation of working people from the products of their labor, including produced natures in various guises (nature being here understood as a historical rather than transcendental category). For Smith, it is this alienation that encourages, in part at least, a dualistic conception of nature seen as external to the social realm; that is, the nature-society dualism is, for Smith, a historical product of capitalist accumulation as biophysical nature is increasingly transformed as and for exchange (on this point, see also Swyngedouw 1999).

From this insight, Smith then reworks the concepts of first and second nature. Traditionally, first nature has been used to refer to pristine or prehistoric natural forms unadulterated by human action. In contrast, second nature has been used to refer to forms of nature that are historical products of social transformations. For Smith, a notion of first nature outside of human histories and geographies, pure and pristine, made less and less sense with the development of global capitalism. Instead, he argued that capitalist production increasingly posits a qualitative shift such that first nature needs to be understood as the set of concrete, material natures produced as use values by capitalist labor processes, whereas second nature needs to be understood as commodified nature or as an exchange value, increasingly manifest as an abstracted notion of fungible nature. Moreover, for Smith, with capitalist production, first nature comes to be produced through second nature, as specific transformations of material nature are guided by the imperatives of nature as an 
abstract, idealized exchange value. With this frame880 work, Smith self-consciously draws a parallel with Marx's conception of the role of abstract social labor in conditioning the production of surplus value from concrete or specific material labor processes in capitalist commodity production.

885 In redefining first nature in particular, Smith elegantly moved off of the entire distinction between pristine nature and natures that have been transformed by human action. This is not to say, we emphasize, that Smith sought to minimize the role of biophysical

890 processes, whether we are talking about gravity, wind, ocean currents, or biological decomposition. Instead, he simply articulated a notion of first nature as a set of material entities and processes with a role in any account of historical-geographical change that is

895 something to be engaged as a matter of contextual contingency and specificity, and more important (for his framing) as a product, in part, of the dynamics of capital accumulation. His category of first nature in this way needs to be seen as fundamentally historicist.

900 That said, Smith was more than aware of the errors of a notion of first nature that might reduce biophysical nature to mere "stuff." Strongly echoing Marx's materialism, including the Theses on Feuerbach (Sayer 1987; Loftus 2009), Smith posited instead material

905 and semiotic production as a simultaneous unity. As he wrote, "[t]he production of consciousness is an integral part of [the] general production of material life" (Smith [1984] 2008, 55). Note the specific phrasing: "part of," not "result of." For Smith, the capitalist pro-

910 duction of nature involves a first nature of conjoined matter and meaning. The metabolic action of human labor in transforming material nature thus also involves the production of ideas, representations, and understandings of nature, featuring a cultural politics

915 of meaning that is internal to the social production of nature, a point foundational to our second article.

In turn, Smith's formulation of second nature becomes a truly alienated nature because its value is determined within capitalist production as a whole by

920 means of the abstraction from use value to exchange value, expressed in terms of the abstract socially necessary labor time required to produce nature in the commodity form. For Smith, only capitalism posits the value of material nature in terms of an abstract social

925 labor that subjects, disciplines, or "determines" (in value terms) specific productions of first nature. As he wrote, "the movement from the abstract to the concrete is not simply a nice ... idea that Marx dreamed up, but is the perpetual translation actually achieved in the relation with nature under capitalism; abstract 930 determinations at the level of value are continually translated into concrete social activity in the relation with nature" (Smith [1984] 2008, 70). This is a crucial and highly original insight, the significance of which, we contend, has not been fully appreciated in the literature. This conception of second nature provides an account of nature's alienation and of the nature-society dualism as specific dimensions of capitalism's production of nature, each grounded in Marx's formulation of the capitalist law of value. Nature (or what we encounter as nature in everyday life) is increasingly subsumed by the logic of exchange and commodification, subordinated "to the creation and accumulation of value which determines the relation with nature under capitalism" (Smith [1984] 2008, 70; see also Smith, 2007). This is arguably Smith's most important, original insight, what we suggest could be called his "capitalist law of nature."

For us, Smith's reformulated notions of first and second nature are hugely consequential. A principal reason for this is that Smith's notion of first nature dissolves the dualism between nature and society in general (as noted) and nature and space specifically by positing space as a subset of a produced first nature; more specifically, space for Smith becomes one aspect of first nature's use value. ${ }^{7}$ Smith's notion of first nature is also inherently historical and his theory historicist in orientation, echoing in this respect the work of Williams (1973), who rendered rural-urban dichotomies as historical and received categories rather than as universal ones. If first nature is simply the historically received and geographically diverse material-semiotic forms in which socionatures make their appearance in shaping and giving meaning to landscapes of various kinds, then indeed there is nothing (ontologically) unnatural about New York City, to paraphrase Harvey. From this we are able to derive that fixed capital formation arising from capital switching is always a form of the production of first nature in general terms, making fixed capital formation an inherently metabolic process, a point we elaborate on in the companion article. In addition, Smith's notion of second nature as an abstract commodified nature, and specifically as what he referred to as "nature as a totality" (Smith [1984] 2008, 81) invites a relational understanding of the production of first nature as concrete space-nature (e.g., a specific dam, a specific wind farm, a particular urban waterfront redevelopment) within the broader context of the production of nature as a whole. As he wrote, "capital stalks 980 
the earth in search of material resources; nature becomes a universal means of production in the sense that it not only provides the subjects, objects, and instruments of production, but is also in its totality an 985 appendage to the production process" (Smith [1984] 2008, 71, italics added). This has far-reaching methodological and political consequences. How, we might ask, do we begin to understand the politics at play in governing any dimension of a specific spatial fix (e.g., ity) within a broader landscape of value determination? How does the credit system, for instance, function in mediating such relationships? Smith does not delve into detail, but the door is clearly open to such avenues of inquiry.

Despite its significance, though, Smith's argument is not without its difficulties for our agenda. First and foremost, as noted previously, Smith did not explicitly examine the idea of a socioecological fix per se. We

1000 infer it. Smith was also not entirely consistent in his account of the relationship between the production of nature and the production of space. Instead, there are occasions in Uneven Development when nature and space are referenced as ontologically separate from one

1005 another, as when Smith ([1984] 2008) argued: "It is the societal mode of production which binds space and nature together into a single landscape" (143). As Uneven Development progresses, produced nature is posited increasingly as content and space as form. For

1010 instance, in a separate piece Smith (2014) commented, "that an insistence on the connections between space and nature-space and the substance that fills it - will help to fulfill the promise of a respatialization of social theory" (12, italics added). Smith did

1015 not fully develop his argument about the production of first and second nature in relation to his account of the production of space. Instead, as Uneven Development moves from the production of nature to the production of space, the question of nature largely falls

1020 from view.

Finally and perhaps most critically, Smith's dialectical reframing of first and second nature, as he bequeathed it to us in Uneven Development, is somewhat one-sided. Specifically, his emphasis on the dom-

1025 ination of first nature and its production from within second nature privileges the abstracted totality of nature as exchange value in relation to the historically and geographically diverse materialities of first nature (Braun 2006) without adequate development of the

1030 internal contradictions involved. As Castree (1995) argued, this tends to elide "both the ontological reality of those entities we term 'natural,' and the active role those entities play in making history and geography" (13). The issue is not whether the processes we call nature are pristine or original. Smith dealt with that problem. Various historically constituted socionatures of everyday life, nevertheless, have properties and dynamics that comprise their use values, and are thus actively involved in shaping their commodification (Prudham 2003; Bakker and Bridge 2006; Eaton 2011; Ekers and Loftus 2013). Mobilizing a metabolic conception of labor requires no less. An overly dominant or deterministic conception of second nature in relation to first nature runs the risk of rendering biophysical processes as passive recipients of social action, reproducing dualistic conceptions of nature and society.

Burkett (1996) articulated this argument effectively. As he noted, socionatures in their diversity clearly comprise part of society's endowment of wealth, expressed in both quantitative and qualitative terms. Yet capitalism recognizes value only in quantitative terms and specifically as abstract commodified social labor. There is therefore a contradiction built into the capitalist law of value in its failure to recognize the material conditions of the production of social wealth and in the abstraction from these material conditions in terms of abstract social labor. Although this is a specific manifestation of the more general contradiction identified by Marx between exchange value and use value within the capitalist law of value, it is also a contradiction internal to the first nature-second nature dialectic posited by Smith, albeit one that is latent in his account.

One aspect of the underdevelopment of this contradiction is that Smith did not privilege the production of nature as a site of social struggle, making Uneven Development economistic as an account of the capitalist production of nature. In our view, this stems in part from Smith's highly original but abstract development of the logic of capitalism's production. Moreover, as he made clear in a later commentary on Uneven Development (Smith [1984] 2008, 249), Smith was interested in confronting the limits of liberal environmentalism in the face of increasing evidence of its cooptation. ${ }^{8}$ Yet, clearly, Smith did posit that social struggle over the production of nature can and should occur, and he was at pains to distance himself from the Frankfurt School emphasis on the so-called domination of nature (Horkheimer, Adorno, and Schmid Noerr 2002). Tellingly, he wrote, "Just as pollutants are integral parts of the production process 
though not its immediate goal, much of the production of nature is not the deliberate goal of production. The pro-

1085 duction process is quite deliberate, but its immediate goal, profit, is reckoned in terms of exchange-value not use-value" (Smith [1984] 2008, 88, italics added). As he then went on to write, "The question really is how we produce nature and who controls this produc1090 tion of nature?" (Smith [1984] 2008, 89).

We agree, but for us, these questions point to a need to see politics as more than something that comes after, or that resists an ontologically prior capitalist production of nature. The production of nature is 1095 political through and through. We close this article with a brief sketch of the concept of the underproduction of nature. In the companion piece to follow, we delve more deeply into the politics of consent and legitimacy when it comes to the metabolism of fixed 1100 capital formation.

\section{Socioecological Crises, Environmental Politics, and the Underproduction of Nature}

To this point, we have put Harvey's theory of the 1105 spatial fix in dialogue with Smith's account of the specifically capitalist production of nature. We have done so with the aim of developing a conception of the socioecological fix; that is, spatial fixes seen as metabolic processes involving the production of space but also 1110 necessarily the transformation of socionatures, whether in urban or rural settings, and whether such transformations are recognized as socionatural in the ideological registers of everyday life (e.g., hydroelectric or irrigation dam infrastructures) or not (e.g., transpor-

1115 tation and telecommunications infrastructure).

In reviewing and synthesizing the work of both scholars, we have also identified a tendency of each to privilege the formal, economic, or value-theoretical dynamics of capital accumulation and crisis tenden-

1120 cies. This privileging has been at the expense of the constitutive role of struggles over the material and ideological dimensions of the production of space and nature, whether it be in crisis formation or in the formation of spatial fixes via capital switching and fixed 1125 capital formation. Yet, as Glassman (2007) noted succinctly, "the very notion of a crisis itself is not given technically, but is produced in and through the process of class struggle" (351), and we would add other kinds of struggle tied to questions of racialization, colonial1130 ism, and gender. Thinking along these lines, and in very general terms, when it comes to fixed capital formation, one of the obvious risks or limitations of relatively long-term investments in the built environment is that the broader milieu of accumulation might change for reasons having to do not only with issues such as technological change, prevailing rates of circulation and turnover times, the organic composition of capital, and the like, but also with evolving social norms and sanctions pertaining to particular kinds of investments. One thinks, for instance, of the 1979 Three Mile Island accident in Pennsylvania and its effect on the conditions of profitability for existing nuclear facilities in the United States as well as in galvanizing public opposition to the expansion of civilian nuclear energy generating capacity. In the contemporary moment, and in response to climate change, increasing pressure is being brought to bear on the fossil fuel industry, up to and including campaigns aimed at inducing individuals and institutions (including, with mixed success to date, atour home institution) to divest from the fossil fuel sector.

In this context, of central importance for our purposes is the way we think about the politics of socionatures, including environmental social movements and the politicization of the environments of everyday life, as these shape the formation and reformation of crises and corresponding fixes (on this point, see also Braun 2006). This suggests we think not only about the production of nature, but also about the possibility of the underproduction of nature.

Here, we draw on O'Connor's $(1988,1998)$ seminal contributions to thinking through (socio-)ecological crises of capitalism. O'Connor, drawing on both Marx and Polanyi, emphasized the problem of reproduction, specifically of reproducing or failing to reproduce the socionatural conditions of capital accumulation or social life more broadly. In the simplest summary terms, O'Connor emphasized the ways in which particular socionatures mobilized and transformed as conditions of commodity production might not be reproduced by individual capitalist firms or by private capital as a whole to the degree necessary either to meet the needs of subsequent accumulation or to sustain social reproduction more generally. Alternatively, some socionatures are produced, as Smith put it, unintentionally, and these could erode the conditions for continued accumulation (at least in its existing guise). This tendency, for O'Connor, is the tendency toward the underproduction of nature.

Curiously, to our knowledge, no systemic link has yet been forged between O'Connor's theory and that

1135 
of Smith, although Castree (2015) recently offered some preliminary remarks. In our view, and using Smith's terminology, the key bridge lies in O'Connor's

1185 suggestion (using Smith's terminology) that the capitalist production of first natures includes both intended and unintended products, the latter including, for instance, unwanted and often unhealthy air and water contaminants (e.g., air or water contamination). In

1190 turn, these unintended products might give rise to impediments (technical, economic, political, or some combination of these) to subsequent accumulation along the same trajectory.

We note a close parallel here between the dynamics

1195 noted by O'Connor vis-à-vis investment in the socionatural conditions of capital accumulation and the tendency for individual firms to underinvest in forms of sunk capital more generally when those forms of sunk capital have a predominantly collective character

1200 either as fixed capital used by numerous firms or sectors, or as items in the consumption fund. ${ }^{9}$ In such instances, recall, complex coalitions of actors (including, variously, multiple firms, finance capital, government agencies, representatives of civil society, etc.)

1205 often come together to resolve collective action problems and organize capital switching from the primary to the secondary or tertiary circuits. In parallel, and as O'Connor suggested, individual firms or clusters of firms might lack the incentive to adequately invest in

1210 reproducing the environmental conditions of their own accumulation. Forest products companies, for instance, might find (and historically at various moments have found) investing in the reproduction of the trees they cut down not to be in their interests

1215 when, for instance, forest tree growth rates are too slow or the risk of fire, drought, or disease makes the investments too tenuous. Under such circumstances, firms could be said to be underproducing nature specifically in the sense of failing to regenerate the condi-

1220 tions of their own accumulation. Struggles over offsetting those costs might also lead to firms playing regions or nations off one another by seeking access to renewed conditions of accumulation in new locations or by seeking to drive down the costs of in situ repro-

1225 duction (for an example of this sort of dynamic involving different environmental regulations under the North American Free Trade Agreement umbrella, see; e.g., McCarthy 2004).

At the same time, to the extent that the socioenvir-

1230 onmental conditions "consumed" without replacement in the context of commodity production also serve to underpin social reproduction (e.g., clean drinking water, healthy air for breathing), then the underproduction of nature takes on a second connotation. O'Connor also stressed this second connotation as a dimension of the underproduction of nature located in the disjuncture between the imperatives of capitalist accumulation and a broader set of contending social claims on particular socioenvironmental conditions. In this respect, O'Connor's notion of the underproduction of nature emphasizes the importance of a contested politics of socionatures as an internal contradiction of capitalism. Contestation centers on the assignation of responsibility for the reproduction of the conditions of production and social reproduction by social movements, factions of capital, the state, and multilateral state-like institutions. O'Connor (1998) specifically argued that "given the politicization of the conditions of production, if these conditions are neglected, and/or their productive powers damaged, there arises the possibility not only of an economic crisis for capital but also of a legitimation crisis for the state or a political crisis for the ruling parties and government" (150).

O'Connor's emphasis on social tensions surrounding the (re)production of nature echoes and draws on insights from Marxist and feminist scholars concerning the contradictory relationship between capitalist production and social reproduction more generally. This interface is important and problematic. One reason is that noncommodified or partially commodified inputs to capitalist accumulation (e.g., public education and health care, human reproduction, household labor, etc.) have historically been important in sustaining capital accumulation as well as social reproduction (Katz 2001; Federici 2004, 2012; Moore 2015). Yet, owing to their noncommodified or partially commodified character (at any given moment within specific historical-geographical contexts), these kinds of services, work, and functions are treated at least partly and by some private firms as "free" or partially free gifts, responsibility for which is systematically displaced, including onto the state or specific social groups, thus not being free of effects and consequences.

Social struggles over the provisioning of such inputs have been and remain hugely important in understanding the politics of capitalist society, including, for example, placing primary and largely unpaid responsibility for biological and household reproduction on women (see, e.g., Federici 2004, 2012; Mies [1986] 2014). Katz (2001) labeled "vagabond capitalism" that form of disengagement that shucks or seeks to displace responsibility for and costs associated with 
social reproduction onto states, nonwaged labor pro1285 cesses, social movements, and so on, and away from the capitalist firms that appropriate these "free gifts." She argued that more attention needs to be paid to these tendencies as inherent features of capital accumulation. We agree and note, as have others, that rec-

1290 ognizing the "extraeconomic" dimensions of historical capital accumulation (i.e., reliance on a logic of appropriation, enclosure, and even theft is one of the central dimensions of Marx's theory of primitive accumulation (see, e.g., De Angelis 2004; Glassman 2006). Inas-

1295 much as socionatural conditions comprise collective forms of fixed capital and the material foundations of social reproduction, these insights, with a distinctly feminist sensibility, align with O'Connor's emphasis on the underproduction of nature as a manifestation of

1300 the tendency toward appropriation of noncommodified or noncapitalized inputs inherent to capitalism, albeit in ways that evolve and shift with historical geographical context (Moore 2011).

Two caveats are necessary here. First, there is noth-

1305 ing necessary about the outcome of struggles over the production and underproduction of nature. Some firms might well see it as being in their interest to invest in producing forms of first nature that sustain them in successive rounds of accumulation, whether-pushed

1310 into more sustainable forms of accumulation or because they recognize that doing so is in their direct interest. The significant shift of investment in the global fishing sector from wild-caught to farmed fish in recent decades suggests as much, although research

1315 also demonstrates systemic efforts to externalize some of the long-term costs associated with aquaculture (DeSombre and Barkin 2011). O'Connor was clear on this point: One response to the underproduction of the conditions of production is the private capitaliza-

1320 tion of those conditions of production in subsequent rounds of investment. We suggest that this is one way for spatial fixes to take on an overtly socioecological character as nature becomes, in Katz's (1998) memorable phrasing, an "accumulation strategy." Here the

1325 underproduction of nature in one moment creates a landscape of investment opportunity, or a possible fix, at another moment for those firms and the coalition of actors interested in producing the conditions of production (or at least suitable substitutes) that were ini1330 tially compromised.

Second, we specifically do not use the phrase underproduction ontologically or, strictly speaking, quantitatively. We are not attempting to smuggle back in some notion of nature as external to or opposite of the social, nor do we seek to embrace a notion of objectively given right or correct conditions of environmental quality and ecosystem function. To put it bluntly, nature cannot define underproduction for us. Although O'Connor's language is at times ambiguous in these regards, and although clearly he has been read ontologically (as it is certainly possible to do), this is not the register in which we seek to draw on his work. Rather, we seek a notion of underproduction that is relational. What constitutes underproduction from the standpoint of one firm might be another's source of profitability. What looks like underproduction from the standpoint of environmental social movements will look quite different to the firms that profit from it. Forest products companies able to secure adequate wood fiber without investing in silviculture might well be rewarded in their bottom line, and for them, the production of clear cuts is the production of first nature as it suits them. For communities reliant on the same forests for other forest products or ecosystem functions delivered by the forests (e.g., habitat for game, landscapes of culture, recreation and leisure, regulation of water quantity and quality, suppression of fire risk, etc.), things look quite different. The point is that there is a tendency woven into the logic of accumulation to "shuck" responsibility as Katz put it (see also Fraser 2014), and that social struggle over the definition of appropriate trajectories of the production of socionatures are endemic to and part of the metabolism of capital accumulation.

Finally, it bears repeating here that socionatures can never connote mere "stuff" (whether alive or not). Instead, socionatures are also sites of contested meanings and representations. Socioecological crises, and all crises for that matter, have conjoined objective and subjective dimensions, and include questions of meaning and legitimation. Specific instances of the underproduction of socionatures turn not only on questions of "How much?" but also questions of "How did this happen?," "What is natural?" (with all the baggage that this question entails), "Who is responsible and who decides?," and "What does it all mean?"

\section{Conclusion: Why Now?}

In this article, we have attempted to provide a rigorous foundation for thinking about the metabolism of spatial fixes. More specifically, we have drawn from and sought to extend or extrapolate Harvey's theorization of crisis-induced investments in the built environment via capital switching, arguing that sunk and fixed
1335 
capital formation need to be recognized explicitly as

1385 avenues by which socionatures are transformed and produced, and thus as forms of socioecological fixes. We have done this in part by drawing on Smith's theory of the specifically capitalist production of nature. Finally, we have drawn on O'Connor's theory of the

1390 underproduction of nature, as well as feminist emphasis on the disjuncture between capitalist production and social reproduction - and the inherently parasitic character of capital accumulation-to emphasize the role of political contestation in shaping socioecologi-

1395 cal fixes.

Our argument is in one sense general. That is, fixed capital and capital sunk into the consumption fund are always, fundamentally, metabolic processes involving the application of social labor to the transforma-

1400 tion of socionatures. In another sense, however, the argument is more immediate. It is ever more the case in the current conjuncture that socionatural transformations comprise explicitly normative terms on which capital investment in landscape change is predicated.

1405 Increasingly, pressure is being placed on states and firms to invest in greener infrastructure, including explicit calls to harness fixed capital investment to targeted "ecological fixes" (Castree and Christophers 2015).

1410 In myriad ways, there is evidence that the landscape of private and public investment in durable assets of various kinds is shifting in response, including, for instance, in the energy sector. As we were finalizing this and its companion article, for example, news

1415 emerged that India could approach deriving 60 percent of its electricity from nonfossil sources by 2027 (Safi 2016). Financial markets are also responding, resulting in what Johnson $(2013,2015)$ described as "catastrophe fixes" developed in response to the

1420 changing contours of risk for long-term capital investments as a consequence of climate change. And, as noted earlier, more and more social pressure is being placed on institutions and investors to divest from the fossil fuel industry, so much so that this has become a

1425 high-profile issue and social movement unto itself.

From various perspectives, then, infrastructure as sunk capital is becoming more and more overtly targeted and contested explicitly in socioecological terms. Diverse coalitions of actors are attempting to

1430 shape capital switching in the name of propelling the trajectory of technological and infrastructural development in more environmentally friendly and, hopefully, more socially progressive directions. Conversely, and as Katz (1998) memorably put it-echoed by Smith
(2007) —nature is becoming ever more targeted as an accumulation strategy. In some instances, the rhetoric of the greening of capitalism might amount to little more than green washing. Some trajectories of socioecological fix might actually exacerbate socioecological crisis tendencies while inducing socially regressive effects, as is increasingly evident in the biofuels sector.

In the most general of terms, although the diversion of capital into enduring forms of infrastructure in response to socioecological concerns might indicate the responsiveness of capital markets to social struggle and contestation, we also need to recognize the converse: The greening of infrastructure by means of the investment of private capital is also a mechanism for securing the reproduction of capitalism. This converse is, in turn, part of a broader institutional and ideological rapprochement between environmentalism on the one hand, and capitalism on the other, that is an underappreciated hallmark of the neoliberal era (McCarthy and Prudham 2004; Büscher et al. 2012). The question posed by Smith in 1984 has only become thereby more immediate: "how [do] we produce nature and who controls this production of nature?" (Smith [1984] 2008, 89).

To answer this and related questions, it is vital to understand at a systemic level the evolving connections between capital switching, fixed capital formation, a politics of socionatures, and the broader architecture of capitalist hegemony. This article provides some steps in that direction, and the companion piece to follow delves more deeply and specifically into the cultural politics of consent and legitimacy as they suffuse the metabolism of capital switching and sunk capital.

\section{Acknowledgments}

Thanks to Bruce Braun for encouraging us to persist with these papers, to James McCarthy for his generosity and guidance in working us through the editorial process with the journal $\boldsymbol{A}_{\boldsymbol{1}}$ and to reviewers for their informed, detailed, and extremely helpful comments. We are grateful for formative feedback on earlier drafts from the members of the Political Economy and Political Ecology research group at the University of Toronto, and from Bram Buscher, Rob Fletcher ${ }_{\bar{\lambda}}$ Alex Loftus, Geoff Mann, and Don Mitchell. Portions the papers were presented at the Historical Materialism 2016 meeting at York University in Toronto, and at the Socialist Studies meetings in Ottawa in 2015. We benefited from comments 
received in both settings. Sam Walker and Heidi Tripp

1485 provided key support as research assistants along the way. We accept responsibility for the final product, including any remaining shortcomings.

\section{Notes}

1. We use the term infrastructure interchangeably with fixed capital and sunk capital in the articles. In current debates, infrastructure is the more widely used term, but as a thoughtful referee suggested, the term is becoming increasingly expansive, perhaps at the expense of analytical precision. We are primarily concerned with infra-

1495 structure as sunk capital and, within this, as fixed capital. We have in mind everything from agricultural landscapes to water facilities to roads to pipelines, whether these are publicly or privately financed and owned, or some combination of both. In the second arti1500 cle, we draw on political ecological studies of infrastructure to discuss the representational and ideological dimensions of fixed capital.

2. See Ekers and Prudham (2015) for a more systematic review of the existing literature on socioecological and sustainable or environmnental regulatory fixes. See also the related series of articles in Environment and Planning A (Vol. 47, Issue 12).

3. It is obviously not quite that simple, as workers are not the only source of demand. Capitalists, landlords, and 1510 other social groups besides workers also buy commodities, for instance. For our purposes, however, this basic dynamic - that is, surplus commodities originating from the exploitative character of the wage relation - as discussed by Marx, not only explains the origins of profit in a capitalist economy, but also points to a structural tendency to overaccumulate and to thus overinvest and overproduce.

4. The concept of fixed capital is relationally contingent on the length of production cycles, which in turn varies by sector.

5. An important caveat to this characterization, and one recognized by Jessop, is Harvey's notion of "structured coherence." This concept represents an attempt to capture the ways in which specific geographies of capitalist accumulation are actively constituted and sustained by relatively enduring combinations of, on the one hand, capital investment, commodity production, and circulation, and on the other hand, by a context of institutional and political influences, including the broad social regulation of economic activities. Although Harvey (1985a) has been criticized for not sufficiently emphasizing cultural processes, he did indeed suggest that "the coherence is reinforced informally, though no less powerfully, through the persistence or creation of national, regional or local cultures and consciousness (including traditions of class struggle) that give deeper psychic meaning to territorial perspectives" (146). It would be fair, however, to say that Harvey did not develop this notion empirically. Moreover, his more formal development of what Jessop called the "value-theoretical" aspects of fixes means that he has written relatively little about how wider social forces come to constitute devaluation crises, spatial fixes, and spatiotemporal fixes ... yet!

6. For an excellent discussion of this danger and a critique of the materialism present in much published scholarship in political ecology, see Mann (2009).

7. In Smith's ([1984] 2008) words, "it would make sense to begin by including the spatial properties of a commodity as among these natural properties and therefore as part of the use-value of a commodity" (111).

8. This phrasing was actually coined by Katz (1998).

9. Similar dynamics of underinvestment in the conditions of production and fixed capital also occur within the private sector because of pressures from shareholders to delay capital outlays or from would-be financial investors with concerns regarding the timing and security of economic returns. Underproduction tendencies in these instances might thus arise not only as a collective action problem but because private capital might be unwilling to make large fixed capital investments in the absence of state financial supports and guarantees, such as was evident in several instances (including in the United States) in the aftermath of the 2007 global financial crisis.

\section{References}

Bakker, K. 2003. An uncooperative commodity: Privatizing water in England and Wales. Oxford, UK: Oxford University Press.

Bakker, K., and G. Bridge. 2006. Material worlds? Resource geographies and the "matter of nature." Progress in Human Geography 30 (1): 5-27.

Braun, B. 2006. Environmental issues: Global natures in the space of assemblage. Progress inHuman Geography 30 (5): 644-54.

Brenner, N. 1998. Between fixity and motion: Accumulation, territorial organization and the historical geography of spatial scales. Environment and Planning D: Society and Space 16 (4): 459-81.

Burkett, P. 1996. Value, capital and nature: Some ecological implications of Marx's critique of political economy. Science $\mathcal{E}$ Society 60 (3): 332.

Büscher, B., S. Sullivan, K. Neves, J. Igoe, and D. Brockington. 2012. Towards a synthesized critique of neoliberal biodiversity conservation. Capitalism Nature Socialism 23 (2): 4-30.

Castree, N. 1995. The nature of produced nature: Materiality and knowledge construction in Marxism. Antipode 27 (1): 12-48.

. 2008. Neoliberalising nature: The logics of deregulation and reregulation. Environment and Planning A 40 (1): 131-52.

2009. The spatio-temporality of capitalism. Time $\mathbb{E}$ Society 18 (1): 26-61.

. 2015. Capitalism and the Marxist critique of political ecology. In The Routledge handbook of political ecology, ed. T. Perreault, G. Bridge, and J. McCarthy, 279292. London and New York: Routledge.

Castree, N., and B. Christophers. 2015. Banking spatially on the future: Capital switching, infrastructure, and the ecological fix. Annals of the Association of American Geographers 105 (2): 378-86.
1545 
Cohen, A., and K. Bakker. 2014. The eco-scalar fix: Rescaling environmental governance and the politics of ecological boundaries in Alberta, Canada. Environment and Planning D: Society and Space 32 (1): $128-46$.

Cowen, D. 2014. The deadly life of logistics: Mapping violence in global trade. Minneapolis: University of Minnesota Press.

1610 De Angelis, M. 2004. Separating the doing and the deed: Capital and the continuous character of enclosures. Historical Materialism 12 (2): 57-87.

DeSombre, E. R., and J. S. Barkin. 2011. Fish. Cambridge, MA: Polity.

1615 Eaton, E. 2011. On the farm and in the field: The production of nature meets the agrarian question. New Political Economy 16 (2): 247-51.

Ekers, M., and A. Loftus. 2013. Revitalizing the production of nature thesis: A Gramscian turn? Progress in Human Geography 37 (2): 234-52.

1620

Ekers, M., and S. Prudham. 2015. Towards the socio-ecological fix. Environment and Planning A 47 (12): 2438 45.

Federici, S. 2004. Caliban and the witch: Women, the body

1625 and primitive accumulation. Brooklyn, NY: Autonomedia.

- 2012. Revolution at point zero: Housework, reproduction, and feminist struggle. Oakland, CA: PM Press.

Foster, J. B. 1999. Marx's theory of metabolic rift: Classical

1630 foundations for environmental sociology. American Journal of Sociology 105 (2): 366-405.

Fraser, N. 2014. Beyond Marx's hidden abode: For an expanded conception of capitalism. New Left Review 86: $55-72$.

1635 Gandy, M. 1999. The Paris sewers and the rationalization of urban space. Transactions of the Institute of British Geographers 24 (1): 23-44.

. 2002. Concrete and clay: Reworking nature in New York City. Cambridge, MA: MIT Press.

1640 Glassman, J. 2006. Primitive accumulation, accumulation by dispossession, accumulation by"extra-economic" means. Progress in Human Geography 30 (5): $608-25$.

. 2007. Recovering from crisis: The case of Thailand's spatial fix. Economic Geography 83 (4): 349_ 70.

Gramsci, A. 1971. Selections from the prison notebooks of Antonio Gramsci. London: Lawrence and Wishart.

1650

Guthman, J. 2004. Agrarian dreams: The paradox of organic farming in California. Berkeley: University of California Press.

. 2011. Weighing in: Obesity, food justice, and the limits of capitalism. Berkeley: University of California Press. 655 and the body as socioecological fix. Environment and Planning A 47 (12): 2522-36.

Hall, S., B. Lumley, and G. McLennan. 1977. Politics and ideology: Gramsci. Cultural Studies 10: 45-76.

Harvey, D. 1975. The geography of capitalist accumulation:

1660 A reconstruction of the Marxiantheory. Antipode 7 (2): 9-21.

1976. Labor, capital, and class struggle around the built environment in advanced capitalist societies. Politics 8 Society 6 (3): 265-95.
1978. The urban process under capitalism: A framework for analysis. International Journal of Urban and Regional Research 2 (1-4): 101-31.

. 1981. The spatial fix-Hegel, Von Thunen, and Marx. Antipode 13 (3): 1-12.

1982. The limits to capital. Oxford, UK: Blackwell.

- 1985a. The geopolitics of capitalism. In Social relations and spatial structures, ed. D. Gregory and J. Urry, 128-63. London: Macmillan.

. 1985b. The urbanization of capital: Studies in the history and theory of capitalist urbanization. Baltimore, MD: Johns Hopkins University Press.

. 1989a. From managerialism to entrepeneurialism: The transformation in urban governance in late capitalism. Geographisca Annaler Series B 71B (1): 3-18. . 1989b. The urban experience. Baltimore, MD: Johns Hopkins University Press.

- 1993. The nature of environment: The dialectics of social and environmental change. Socialist Register 29: $1-51$.

1996. Justice, nature, and the geography of difference. Cambridge, MA: Blackwell.

2001. Globalization and the spatial fix. Geographische Revue 2: 23-30.

Hegel, G. W. F. [1821]1991. Hegel: Elements of the philosophy of right. Cambridge, UK: Cambridge University Press.

Henderson, G. 1999. California Eु the fictions of capital. New York: Oxford University Press.

Herod, A. 1997. From a geography of labor to a labor geography: Labor's spatial fix and the geography of capitalism. Antipode 29 (1): 1-31.

Heynen, N., M. Kaika, and E. Swyngedouw, eds. 2006. In the nature of cities: Urban political ecology and the polics of urban metabolism. London and New York: Routledge.

Horkheimer, M., T. W. Adorno, and G. Schmid Noerr. 2002. Dialectic of enlightenment: Philosophical fragments. Stanford, CA: Stanford University Press.

Huber, M. 2013. Lifeblood: Oil, freedom, and the forces of capital. Minneapolis: University of Minnesota Press.

Jessop, B. 2006. Spatial fixes, temporal fixes and spatio-temporal fixes. In David Harvey: A critical reader, ed. N. Castree and D. Gregory, 142-66. Oxford, UK: Blackwell.

Johnson, L. 2013. Catastrophe bonds and financial risk: Securing capital and rule through contingency. Geoforum 45 (2): 30-40.

- 2015. Catastrophic fixes: Cyclical devaluation and accumulation through climate change impacts. Environment and Planning A 47 (12): 2503-21.

Kaika, M. 2005. City of flows: Modernity, nature, and the city. London and New York: Routledge.

Kaika, M., and E. Swyngedouw. 2000. Fetishizing the modern city: The phantasmagoria of urban technological networks. International Journal of Urban and Regional Research 24 (1): 120-38.

Katz, C. 1998. Whose nature, whose culture? Private productions of space and the "preservation" of nature. In Remaking reality: Nature at the millenium, ed. B. Braun and N. Castree, 46-63. London and New York: Routledge.

- 2001. Vagabond capitalism and the necessity of social reproduction. Antipode 33 (4): 709-28. 
Kear, M. 2007. Spaces of transition spaces of tomorrow: Making a sustainable future in Southeast False Creek, Vancouver. Cities 24 (4): 324.

1730 Keil, R. 2003. Urban political ecology 1. Urban Geography 24 (8): 723-38.

Lang, R., and P. Knox. 2009. The new metropolis: Rethinking megalopolis. Regional Studies 43 (6): 789-802.

1735 ecology of the possible. Area 41 (2): 157-66.

Loftus, A., and H. March. 2016. Financializing desalination: Rethinking the returns of big infrastructure. International Journal of Urban and Regional Research 40 (1): 46-61.

Macdonald, S., and R. Keil. 2012. The Ontario Greenbelt:

1740 Shifting the scales of the sustainability fix? The Professional Geographer 64 (1): 124-45.

Mann, G. 2009. Should political ecology be Marxist? A case for Gramsci's historical materialism. Geoforum 40 (3): 335-44.

1745 Marx, K. [1867]1977. Capital: A critique of political economy. Volume 1. New York: Vintage.

- [1858]1981. Grundrisse: Foundations of the critique of political economy (rough draft). Harmondsworth, UK: Penguin.

1750 McCarthy, J. 2015. A socioecological fix to capitalist crisis and climate change? The possibilitiesand limits of renewable energy. Environment and Planning A 47 (12): 2485-2502.

1755

- 2004. Privatizing conditions of production: Trade agreements as neoliberal environmental governance. Geoforum 35 (3): 327-41.

McCarthy, J., and S. Prudham. 2004. Neoliberal nature and the nature of neoliberalism. Geoforum 35 (3): 275-83.

Mies, M. [1986]2014. Patriarchy and accumulation on a world scale: Women in the international division of labour. London: Zed.

Mitchell, D. 1996. The lie of the land: Migrant workers and the California landscape. Minneapolis: University of Minnesota Press.

1765 . 2000. Cultural geography: A critical introduction. Oxford, UK: Blackwell.

- 2003. Dead labour and the political economy of landscape-California living, California dying. In Handbook of cultural geography, ed. K. Anderson, 233248. London: Sage.

Moore, J. 2011. Transcending the metabolic rift: A theory of crises in the capitalist world ecology. Journal of Peasant Studies 38 (1): 1-46.

. 2015. Capitalism in the web of life. London: Verso.
Nugent, J. P. 2015. Ontario's infrastructure boom: A socioecological fix for air pollution, congestion, jobs, and profits. Environment and Planning A 47 (12): 2465-84.

O'Connor, J. 1988. Capitalism, nature, socialism: A theoretical introduction. Capitalism, Nature, Socialism 1 (1): $11-38$.

. 1998. Natural causes: Essays in ecological Marxism. New York: Guilford.

Prudham, S. 2003. Taming trees: Capital, science, and 1785 nature in Pacific Slope tree improvement. Annals of the Association of American Geographers 93 (3): 636-56.

Rehmann, J. 2014. Theories of ideology: The powers of alienation and subjection. Chicago: Haymarket.
Safi, M. 2016. India plans nearly $60 \%$ of electricity capacity from non-fossil fuels by 2027. TheGuardian 22 December 2014. https://www.theguardian.com/world/2016/ $\mathrm{dec} / 21 /$ indiarenewable-energy-paris-climate-summittarget?CMP=Share_iOSApp_Other (last accessed 5 January 2017).

Sayer, D. 1987. The violence of abstraction: The analytic foundations of historical materialism. Oxford, UK: Blackwell.

Sayre, N. F. 2010. Climate change, scale, and devaluation: The challenge of our built environment. Washington and Lee Journal of Energy, Climate and Environment 1 (1): 93-105.

Smith, N. 2007. Nature as accumulation strategy. In The socialist register 2007, ed. L. Panitch and C. Leys, 16-36. Monmouth, UK: Merlin.

-. [1984]2008. Uneven development: Nature, capital and the production of space. Athens: The University of Georgia Press.

- 2014. Space and substance in geography. In Envisioning human geographies, ed. P. Cloke, P. Crang and M. Goodwin, 11-29. London and New York: Routledge.

Sullivan, S. 2013. Banking nature? The spectacular financialization of envirenmental conservation. Antipode 45 (1): $198 \quad 217$.

Swyngedouw, E. 1999. Modernity and hybridity: Nature, regeneracionismo, and the production of the Spanish waterscape, 1890-1930. Annals of the Association of American Geographers 89 (3): 443.

-2015. Liquid power: Water and contested modernities in Spain, 1898-2010. Cambridge, MA: MIT Press.

Swyngedouw, E., and N. Heynen. 2003. Urban political ecology, justice and the politics of scale. Antipode 35 (5): 898-918.

Thomas, P. D. 2009. The Gramscian moment: Philosophy, hegemony and Marxism. Leiden, The Netherlands: Brill.

Torrance, M. 2008. Forging glocal governance? Urban infrastructures as networked financial products. International Journal of Urban and Regional Research 32 (1): 1-21.

Urry, J. 2004. The "system" of automobility. Theory, Culture हु) Society 21 (4-5): 25-39.

Walker, R. A. 1981. A theory of suburbanization: Capitalism and the construction of urban space in the United States. In Urbanization and urban planning in capitalist society, ed. M. Dear and A. Scott, 383-429.

. 2004. The spectre of Marxism: The return of the limits to capital. Antipode 36 (3): 434-43.

While, A., A. E. G. Jonas, and D. Gibbs. 2004. The environment and the entrepreneurial city: Searching for the urban "sustainability fix" in Manchester and Leeds. International Journal of Urban and Regional Research 28 (3): 549-69.

Williams, R. 1973. The country and the city. London: Verso.

Wyly, E., M. Atia, and D. Hammel. 2004. Has mortgage capital found an inner-city spatial fix? Housing Policy Debate 15 (1): 623-85.

MICHAEL EKERS is an Assistant Professor in the Department of Human Geography at the University of Toronto, Scarborough. E-mail: michael.ekers@utsc.utoronto.ca. His current research draws on debates on the political economy

1790 
of nature and agrarian change to understand the financiali1850 zation of forestlands in British Columbia, Canada, and the role and significance of interns and apprentices in staffing
SCOTT PRUDHAM is a Professor in the Department of Geography and Planning, cross-appointed to the School of the Environment at the University of Toronto. E-mail: scott.prudham@utoronto.ca. His research interests lie at the intersection of political economy and environmental change, with a current focus on long-term agrarian transformation, village-level production cooperatives, and conjoined socioenvironmental change in the wine sector of Languedoc, France.
1855 